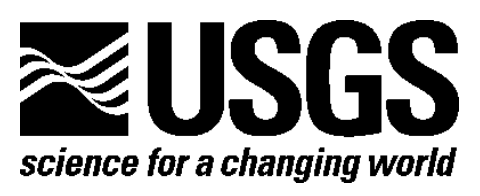

\title{
2018 Report on Incorporating Sedimentary Basin Response into the Design of Tall Buildings in Seattle, Washington
}

By Erin A. Wirth, Susan W. Chang, and Arthur D. Frankel

Open-File Report 2018-1149

U.S. Department of the Interior

U.S. Geological Survey 


\section{U.S. Department of the Interior \\ RYAN K. ZINKE, Secretary}

\section{U.S. Geological Survey James F. Reilly II, Director}

U.S. Geological Survey, Reston, Virginia: 2018

For more information on the USGS-the Federal source for science about the Earth, its natural and living resources, natural hazards, and the environment-visit https://www.usgs.gov/ or call 1-888-ASK-USGS (1-888-275-8747).

For an overview of USGS information products, including maps, imagery, and publications, visit https://store.usgs.gov/.

Any use of trade, firm, or product names is for descriptive purposes only and does not imply endorsement by the U.S. Government.

Although this information product, for the most part, is in the public domain, it also may contain copyrighted materials as noted in the text. Permission to reproduce copyrighted items must be secured from the copyright owner.

Suggested citation:

Wirth, E.A., Chang, S.W., and Frankel, A.D., 2018, 2018 report on incorporating sedimentary basin response into the design of tall buildings in Seattle, Washington: U.S. Geological Survey Open-File Report 2018-1149, 19 p., https://doi.org/10.3133/ofr20181149. 


\section{Acknowledgments}

We thank the workshop attendees for their participation, insightful comments, and recommendations. We especially thank Norm Abrahamson, Kevin Aswegan, Ken Campbell, C.B. Crouse, Doug Lindquist, Hamilton Puangnak, Andreas Skarlatoudis, Andy Taylor, and Melanie Walling for providing summaries of their presentations for this report, as well as Nasser Marafi for contributing figures and analyses. Scott Pawling provided detailed notes of the workshop discussions. Morgan Moschetti and Jeffrey Berman provided helpful comments that improved the report. We also thank Brian Sherrod (U.S. Geological Survey) for his support and for providing travel funds for the workshop.

\section{Contents}

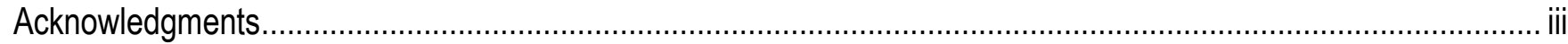

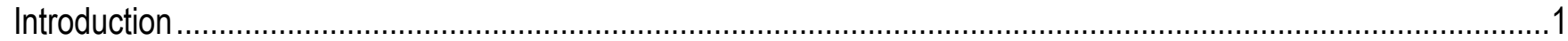

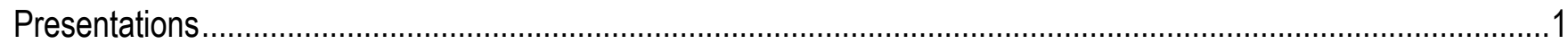

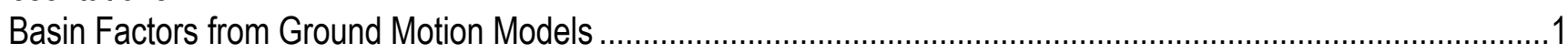

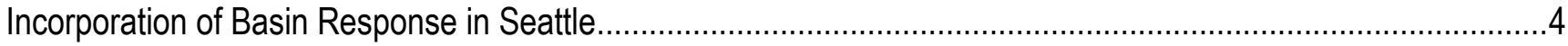

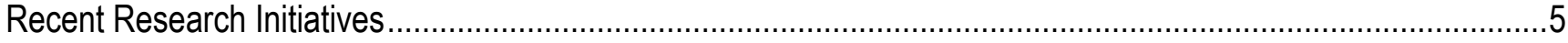

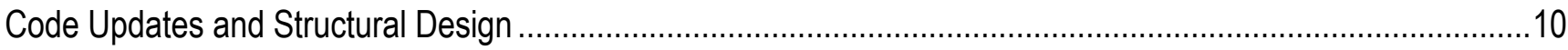

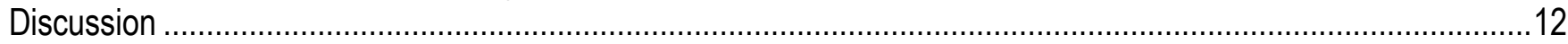

Applicability of Ground Motion Models and Basin Amplification Factors to Subduction Zone

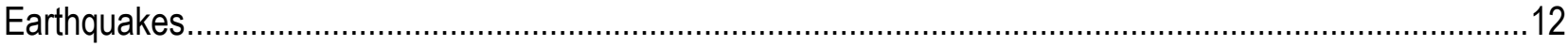

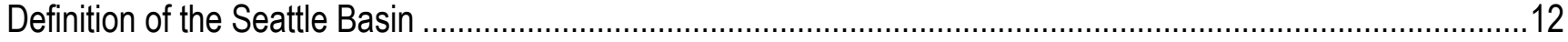

The Influence of Reference Site on Basin Amplification Terms................................................................13

Regional Variations among Sedimentary Basins...................................................................................14

Recommendations by the Workshop Participants ............................................................................... 14

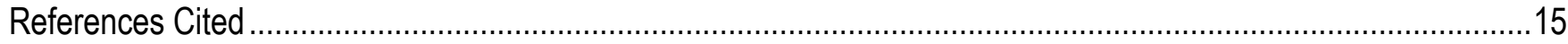

Appendix

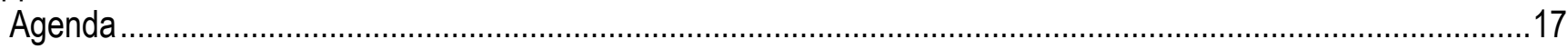

\section{Figures}

1. Campbell and Bozorgnia (2014) basin amplification factors as a function of basin depth for various

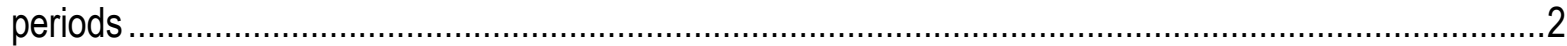

2. Maximum considered earthquake $\left(M E_{R}\right)$ spectrum with and without basin amplification compared to building design codes .......................................................................................................

3. Basin amplification factors as a function of period for various subduction zone earthquakes and four sedimentary basins in Japan.

4. Basin amplification factors determined for sites within the Seattle basin relative to a thin soil-and-rock site (seismic station BRI), based on two earthquakes.................................................................

5. Map of select seismic stations in and around the Seattle basin and Amplification of Seattle basin sites relative to a rock site outside the basin, as a function of period

6. Seattle basin showing the depth to 2.5 kilometers per second shear wave velocity $\left(Z_{2.5}\right)$ and Basin amplification as a function of period for the $M 9$ simulations, using the $Z_{2.5}$ criteria and station averages

7. Geologic definition of the Seattle basin, based on depth-to-basement estimates and the location of the Seattle Fault 


\section{Abbreviations}

ASCE American Society of Civil Engineers

BAF basin amplification factor

GMM ground motion model

$\mathrm{MCE}_{\mathrm{R}} \quad$ risk-targeted maximum considered earthquake

NSHM National Seismic Hazard Map

PSHA probabilistic seismic hazard analysis

SDCl Seattle Department of Construction and Inspections

USGS U.S. Geological Survey 


\title{
2018 Report on Incorporating Sedimentary Basin Response into the Design of Tall Buildings in Seattle, Washington
}

\author{
By Erin A. Wirth, Susan W. Chang, and Arthur D. Frankel
}

\section{Introduction}

On March 22, 2018, the Seattle Department of Construction and Inspections (SDCI) and the U.S. Geological Survey (USGS) convened a workshop of engineers and seismologists to provide guidance on incorporating sedimentary basin response into the design of tall buildings in Seattle. This workshop provided recommendations that build on those from a March 2013 workshop (Chang and others, 2014), primarily based on new results from 3-D simulations of magnitude $(M) 9$ Cascadia earthquakes (The M9 Project). Susan Chang, a geotechnical engineer with the Seattle Department of Construction and Inspections, organized and led the workshop; Art Frankel (USGS) assisted in constructing the agenda.

The workshop agenda and attendees are provided in the appendix. The attendees represented a wide range of expertise, including seismologists with expertise in ground motions and basin response, geotechnical engineers, and structural engineers. Their professional experience included working on local projects related to the design of long-period structures; peer reviewing ground motions for performance-based design of high-rises in Seattle; researching basin response in academic, government and industry settings; developing ground motion models; and representing local and national structural engineering organizations. In this report, we summarize the technical presentations, key discussion points, and recommendations from the workshop.

\section{Presentations}

\section{Basin Factors from Ground Motion Models}

The first session of the workshop provided an overview of how basin terms are developed for ground motion models (GMMs) for crustal sources. Key topics included approaches for incorporating basin amplification factors from 3-D simulations into estimates of earthquake ground motions and seismic hazard, as well as the status of incorporating basin terms into the 2018 USGS National Seismic Hazard Maps (NSHMs).

Ken Campbell summarized the basis for the basin amplification term in the Campbell and Bozorgnia (2014; hereafter, CB14) Next Generation Attenuation for the western United States (NGAWest2) ground motion model. The functional form of the basin amplification term is primarily based on the 3-D numerical ground motion simulations of basin effects in the Los Angeles area conducted by Day and others (2008). Day and others computed long-period response spectra (2-10 s) from 60 regional earthquake scenarios (M6.3-7.1), using the Southern California Earthquake Center Community Velocity 
Model. Three basin depths were considered for parameterizing the results of the simulations: $Z_{1.0}$ (the depth to 1.0 kilometer per second $\left[\mathrm{km} / \mathrm{s}\right.$ ] shear wave velocity), $Z_{1.5}$, and $Z_{2.5}$. Equations were developed that related basin amplification to basin depth, including both the 1-D and 3-D response of the sediments; the basin amplification factors are relative to the 1-D response of a $3.2 \mathrm{~km} / \mathrm{s}$ reference rock site.

The CB14 basin amplification terms were developed using the mathematical relations from Day and others (2008). $Z_{2.5}$ was chosen as the depth parameter in the term because of its strong correlation with basin amplification and its ability to be estimated from geological and geophysical data. To establish the CB14 basin amplification terms, the relation between residuals (from a GMM with a term for average shear wave velocity in the uppermost 30 meters [ $\left.V_{\mathrm{S} 30}\right]$ and no basin term) and basin depth was examined at periods of $0.01-10 \mathrm{~s}$. Decreasing residuals were found between $\mathrm{Z}_{2.5}=0-1 \mathrm{~km}$, no residual trend was found for $Z_{2.5}=1-3 \mathrm{~km}$, and there were increasing residuals between $Z_{2.5}=3-7 \mathrm{~km}$. The increasing trend $(3-7 \mathrm{~km})$ was fit by empirically calibrating the Day and others (2008) functional form; the decreasing $(<1 \mathrm{~km})$ trend was fit using an empirically based functional form.

The CB14 basin amplification factors as a function of period are shown in figure 1. It indicates that the pseudo-spectral acceleration basin amplification factor is nearly a factor of 2 at a period of $10 \mathrm{~s}$ and basin depth of $10 \mathrm{~km}$.

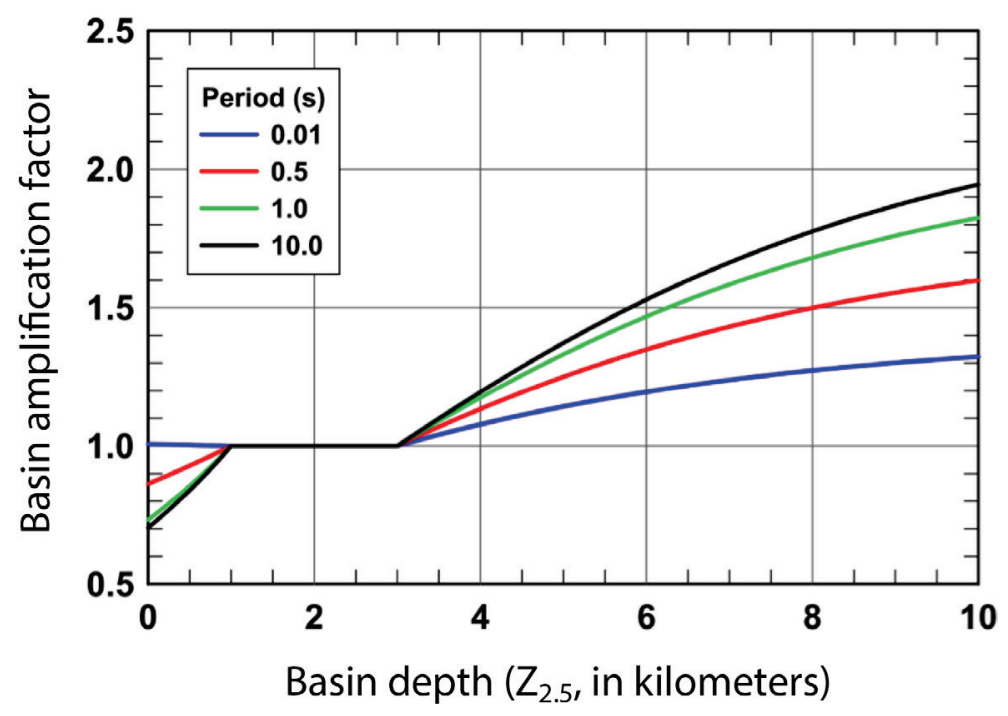

Figure 1. Campbell and Bozorgnia (2014) basin amplification factors as a function of basin depth for various periods. $Z_{2.5}$, the depth to 2.5 kilometers per second shear wave velocity; s, seconds.

Norm Abrahamson described how basin terms were developed for the NGA-West1 Abrahamson and Silva (2008; hereafter AS08) and NGA-West2 Abrahamson and others (2014; hereafter, ASK14) GMMs. Abrahamson also noted key issues in constraining basin effects, including (1) correlations and tradeoffs between $\mathrm{Z}_{1.0}$ (or $\mathrm{Z}_{2.5}$ ) and $V_{\mathrm{S} 30}$, (2) regional dependence of basin effects owing to unique 3-D crustal structure and earthquake source azimuths, and (3) the need to center basin terms on a particular GMM.

In the NGA-West1 AS08 model, 3-D simulations from the Los Angeles basin were used to constrain the basin effects relative to a 1-D simulation with the same source. The basin amplification terms (based on $\mathrm{Z}_{1.0}$ ) were centered on the AS08 GMM by accounting for the amount of the basin effect that was explained by the correlation between $V_{\mathrm{S} 30}$ and $\mathrm{Z}_{1.0}$. 
In the NGA-West2 ASK14 model, basin effects were based on an empirical regression of a large number of recordings. The correlation between $V_{\mathrm{S} 30}$ and $\mathrm{Z}_{1.0}$ was addressed by normalizing the basin scaling by the median $\mathrm{Z}_{1.0}$ value for a given $V_{\mathrm{S} 30}$. This centers the basin scaling on the GMM, but depends on the empirical data set used and the $V_{\mathrm{S} 30}$ scaling in the GMM. Therefore, it may not be appropriate to apply basin amplification terms from one GMM to other GMMs with different $V_{\mathrm{S} 30}$ scaling.

To center basin amplification factors derived from 3-D simulations on specific GMMs, Abrahamson proposed using 1-D crustal models that lead to simulated 1-D ground motions that are consistent with the GMM scaling (in other words, this 1-D crustal model should be similar to the reference site condition in the GMM). Abrahamson stated that the failure to center results on the GMMs is one of the main reasons that 3-D simulations are not currently used in site-specific probabilistic seismic hazard analysis studies.

Art Frankel reported on the March 8-9, 2018, meeting regarding the next update of the USGS National Seismic Hazard Maps. For the 2018 NSHMs, the basic products are planned to be a suite of probabilistic ground motions at several periods and values of $V_{\mathrm{S} 30}$. The design spectra will be constructed from this suite of periods rather than from just two spectral ordinates at 0.2 and $1.0 \mathrm{~s}$, as in current practice.

Various strategies were discussed at the March 9 meeting for including basin amplification factors in the 2018 NSHMs. It was generally agreed to include basin amplification in only limited areas that have 3-D seismic velocity models based on seismic tomography, seismic reflection/refraction, and (or) borehole data. Therefore, basin factors would be included for the Seattle-Tacoma, San Francisco Bay, Los Angeles, and Salt Lake City regions. These factors would be taken from the basin factors in the NGA-West2 GMMs based on strong motion recordings of crustal earthquakes. It was also proposed that results of 3-D simulations would be considered for the basin amplification factors in the 2020 update of the NSHMs.

For the Seattle-Tacoma region, Frankel proposed that the 2018 NSHMs include basin amplification factors for areas with $\mathrm{Z}_{2.5} \geq 3.0 \mathrm{~km}$, consistent with the findings of Campbell and Bozorgnia (2014). These basin factors would be determined from the $Z_{2.5}$ in the 3-D velocity model of Stephenson and others (2017). The CB14 factors would be applied to the GMMs used for subduction interface, intraslab, and crustal earthquakes. Basin factors from other NGA-West2 GMMs are also being considered for crustal earthquakes, by converting the $\mathrm{Z}_{2.5}$ values to $\mathrm{Z}_{1.0}$ using an empirical relation. There were some concerns raised about applying the CB14 factors to GMMs based on observations in Japan, because the $V_{\mathrm{S} 30}$ terms could be different between Japan, where the subduction zone data was recorded, and California, where most of the crustal earthquake data were recorded. This issue was going to be evaluated before construction of the draft 2018 NSHMs.

Melanie Walling, Ken Campbell, and Norm Abrahamson briefly addressed the new NGASubduction GMMs, which are expected to be completed in June 2018. Ultimately, the NGA-Subduction GMMs should include basin terms, although the timeframe for including basin effects was unclear.

In the future, NGA-Subduction GMMs will be used for evaluating shaking intensity resulting from interface earthquakes, but it is likely that the basin terms will not be representative of basin amplification in the Seattle basin. Abrahamson and Walling noted that in order to center Seattle-specific basin terms on the GMM from 3-D simulations or observations, they will need to be normalized by a reference $\mathrm{Z}_{2.5}$ or $V_{\mathrm{S}}$ profile from the GMM dataset.

Melanie Walling also noted the importance of lowering the ergodic sigma (the standard deviation found in GMMs based on global datasets) to account for the inclusion of basin terms. An active research question is whether the standard deviation of spectral accelerations is higher in basins. 
Art Frankel noted that the $M 9$ 3-D simulations did not indicate a systematic difference in inter-event sigma between basin sites and non-basin sites; sigma was found to be large for sites close to the rupture, owing to rupture directivity and proximity to high stress drop (strong motion generating) subevents.

\section{Incorporation of Basin Response in Seattle}

Hamilton Puangnak and Melanie Walling summarized GeoEngineers' approach for incorporating basin amplification effects in the design of tall buildings in Seattle. Basin amplification factors are computed separately for each source type (crustal, intraslab, and interface). The crustal basin amplification factors are determined from the Campbell and Bozorgnia (2014) GMM, which is parameterized by $\mathrm{Z}_{2.5}$. GMMs parameterized by $\mathrm{Z}_{1.0}$ are not used, owing to the lack of a correlation between $Z_{1.0}$ and deeper seismic velocity structure in the Seattle basin. The crustal basin amplification factors range from about 1.2 to 1.7 for spectral periods as long as $10 \mathrm{~s}$. Basin amplification factors for intraslab earthquakes are derived from observed basin amplification at select recording stations situated around downtown Seattle during the 2001 M6.8 Nisqually and 2004 M6.4 Vancouver Island intraslab earthquakes (Chang and others, 2014). The intraslab basin amplification factors range from about 1.3 to 2.2 for spectral periods from 0.5 to $10 \mathrm{~s}$. Basin amplification factors for interface earthquakes are based on preliminary 3-D simulations of magnitude 9 Cascadia interface earthquakes (Frankel and Stephenson, 2015). The interface basin amplification factors range from about 1.3 to 1.7 for spectral periods from 2.0 to $10 \mathrm{~s}$; these amplification factors were computed from 3-D simulations that used the Delorey and Vidale (2011) basin model, which has since been shown to smooth out the south edge of the Seattle basin.

To incorporate basin amplification factors into a risk-targeted maximum considered earthquake $\left(\mathrm{MCE}_{\mathrm{R}}\right)$ spectrum, a weighted-average basin amplification factor is computed based on the percent contribution of each source type to the total hazard on a period-by-period basis; the percent contribution is adopted from the probabilistic seismic hazard analysis (PSHA) deaggregation results at the period of interest. The crustal and intraslab basin amplification factors tend to dominate at spectral periods $<0.5 \mathrm{~s}$, and the crustal and interface basin factors dominate at periods $>0.5 \mathrm{~s}$. An improvement to this approach would be to propagate the full distribution of epistemic and aleatory uncertainty in the basin factors to the design values. However, this approach is limited by the number of credible models available, quantifying the uncertainties in these models, and the requirements of the structural design.

Doug Lindquist summarized Hart Crowser's procedure for generating a site-specific MCER spectrum for sites in downtown Seattle. The procedure begins with a PSHA using a site-specific shear wave velocity $\left(V_{\mathrm{S} 30}\right)$, which is generally determined by testing at the site of interest. This generates geometric mean spectral accelerations for a uniform hazard spectrum corresponding to a return period of 2,475 years. This PSHA uses the default basin terms (relying on $\mathrm{Z}_{1.0}$ or $\mathrm{Z}_{2.5}$, based on the $V_{\mathrm{S} 30}$ of the site) in the NGA-West2 GMMs.

To develop the basin amplification factors for sites in the Seattle basin, the four NGA-West2 GMMs with explicit basin terms are used. The basin amplification factors are simply the ratio of the predicted median response spectrum for a site within the Seattle basin (using site-specific basin depths) and outside the Seattle basin (using default GMM basin depths). The site-specific basin depths are determined using the velocity model by Delorey and Vidale (2011) for $\mathrm{Z}_{1.0}$ and Stephenson and others (2017) for $Z_{2.5}$. The 2013 workshop (Chang and others, 2014) concluded that the $Z_{2.5}$ parameter used in the Campbell and Bozorgnia (2014) GMM was a more appropriate predictor of basin response than $Z_{1.0}$ (used in three other GMMs) for sites with inversions in the $\mathrm{Z}_{1.0}$ basin depth, such as some areas of Seattle. Therefore, a 50 percent weight was assigned to the basin amplification factors calculated by Campbell and Bozorgnia, with the other three GMMs splitting the remaining 50 percent weight evenly. 
Although these GMMs were developed for crustal hazard, Hart Crowser considered this approach appropriate for all earthquake types until results of basin amplification from interface and intraslab earthquakes were properly validated and available.

A typical MCER spectrum with and without basin amplification factors compared to the codebased MCER spectra developed using American Society of Civil Engineers (ASCE) 7-10 and ASCE 716 is shown in figure 2. Inclusion of basin amplification causes the design spectrum to exceed the codebased spectrum over a wide range of periods.

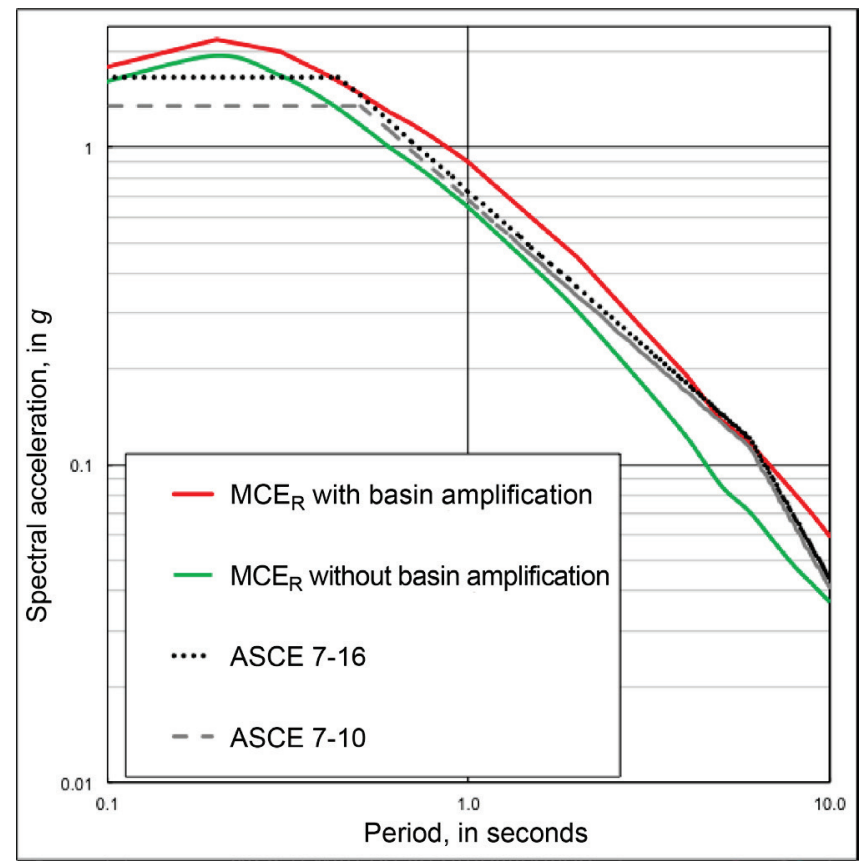

Figure 2. Maximum considered earthquake $\left(M E_{R}\right)$ spectrum with (red) and without (green) basin amplification compared to building design codes. Figure courtesy of Doug Lindquist, Hart Crowser. ASCE, American Society of Civil Engineers; g, acceleration due to gravity; MCE, maximum considered earthquake.

\section{Recent Research Initiatives}

Art Frankel presented recorded observations of basin amplification in Japan and Seattle. Recent work by Marafi and others (2017) examined the effects of basin amplification from multiple subduction zone earthquakes on four sedimentary basins in Japan - the Kanto and Niigata basins in central Japan and the Yufutsu and Konsen basins in northern Japan. The BC Hydro GMM (Abrahamson and others, 2016) was used to calculate residuals for stations inside and outside the basin; a basin amplification factor $\left(B A F_{\mathrm{Sa}}\right)$ was determined by taking the geometric mean of residuals inside the basin, defined as $\mathrm{Z}_{2.5} \geq 3 \mathrm{~km}$, normalized by the residuals outside the basin, $\mathrm{Z}_{2.5}<1.5 \mathrm{~km}$. The basin amplification factors using subduction zone earthquakes of various magnitudes for each of the Japanese basins are compared to the $B A F_{\mathrm{Sa}}$ for the Puget Lowland during the 2001 Nisqually earthquake in figure 3 . Basin amplification factors were computed using the same inside- and outside-basin criteria for the Japanese and Nisqually earthquakes. Plots of $B A F_{\mathrm{Sa}}$ as a function of period demonstrate that the Yufutsu basin provides the closest match to the Nisqually data in terms of trend and amplitude. Conversely, the Kanto basin exhibits basin amplification factors that are significantly lower at long-periods $(>1 \mathrm{~s})$ than those derived from the Nisqually data; amplification factors are relatively uniform for periods of $1-10 \mathrm{~s}$. In a 
separate study, Denolle and others (2014) also noted that the strength of Kanto basin amplification is highly dependent on the direction of incoming seismic waves. These works highlight the pitfalls of deriving basin amplification factors from other basins and applying them to the Seattle basin.

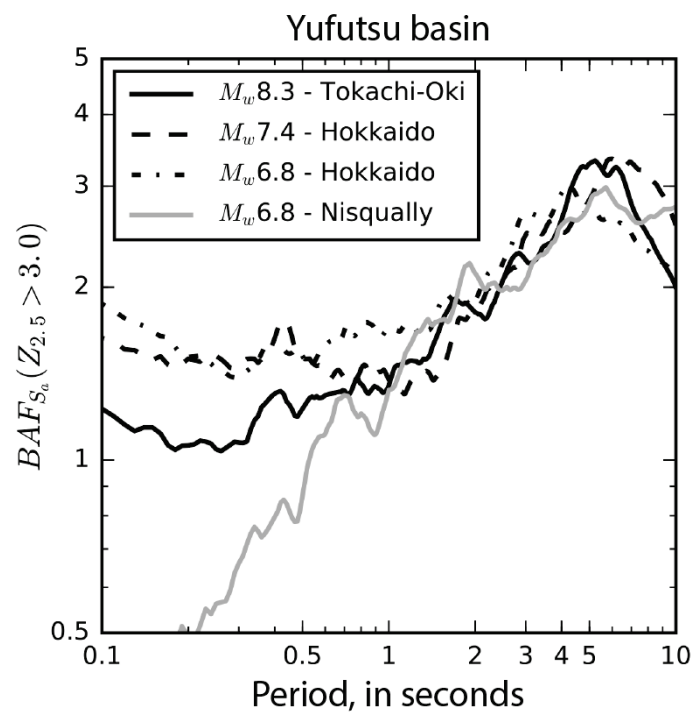

(a)

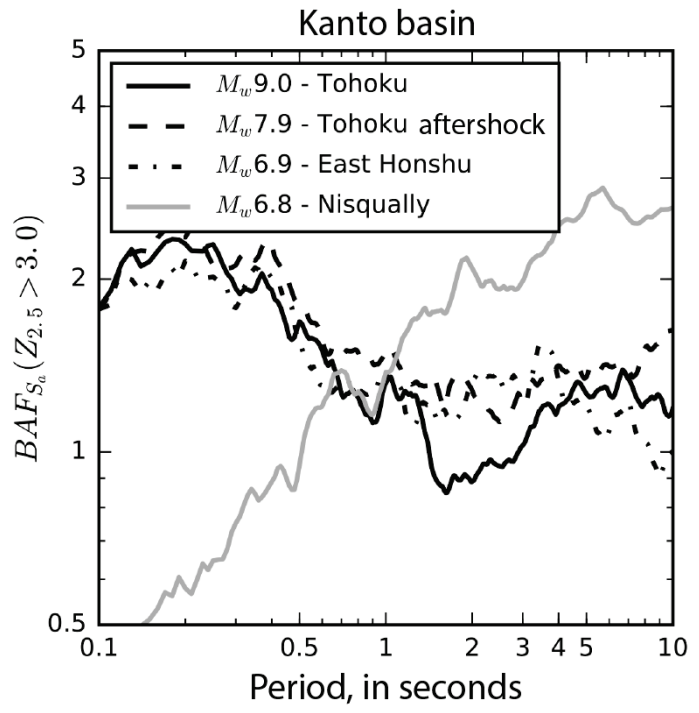

(c)

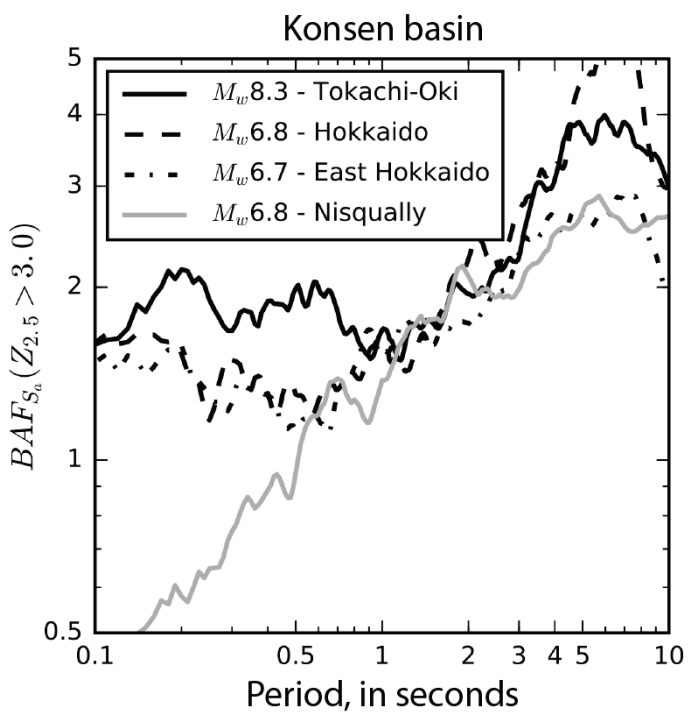

(b)

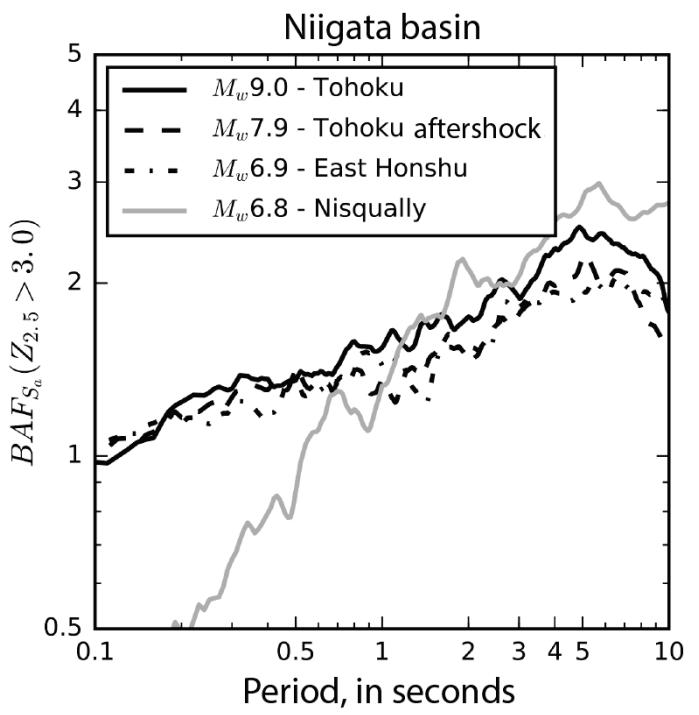

(d)

Figure 3. Basin amplification factors as a function of period for various subduction zone earthquakes and four sedimentary basins in Japan (black). Seattle basin amplification factors from the 2001 Nisqually earthquake are also shown (gray). Reproduced from Marafi and others (2017). BAFsa, basin amplification factor; $\mathrm{M}_{\mathrm{w}}$, moment magnitude; $Z_{2.5}$, the depth to 2.5 kilometers per second shear wave velocity.

Returning to observations in the Seattle region, Frankel showed amplification factors derived for a subset of local earthquakes (fig. 4) and emphasized the importance of the outside-basin reference site. Amplification factors are increased when a reference site outside of the Puget Lowland is used (for example, the Olympic Mountains), compared to thin soil sites just outside of the Seattle basin. 
Frankel also presented validation of the 3-D model for the Seattle basin using four local earthquakes (Frankel and others, 2009). This validation consisted of calculating residuals between spectral accelerations derived from observed data and simulated seismograms, as well as accurately modeling the observed amplification of Fourier spectral amplitudes (1 hertz [Hz]) by the Seattle basin. Long-period waveforms of the Nisqually earthquake and an $M 4.8$ earthquake were also successfully modeled. Frankel noted that an interim version of the 3-D seismic velocity model used for the 2015 M9 simulations produced synthetics that underestimated the Seattle basin amplification. This interim model was based on the tomography results of Delorey and Vidale (2011), which smoothed the south edge of the Seattle basin (the Seattle Fault) compared to the geologically constrained south boundary used in the earlier simulations. The current $M 9$ simulations use the Seattle basin model applied in Frankel and others (2009), which was derived from geologic constraints and validated against data.
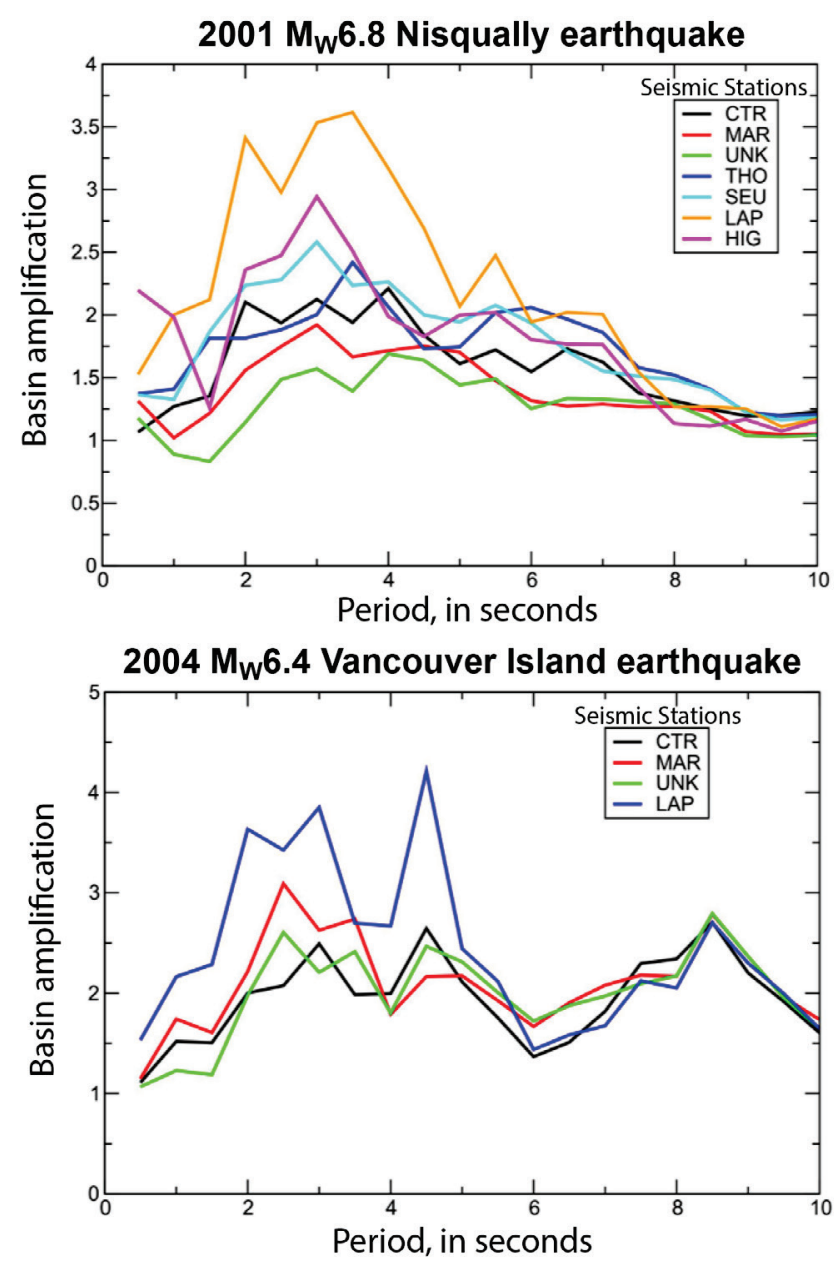

Figure 4. Basin amplification factors determined for sites within the Seattle basin relative to a thin soil-and-rock site (seismic station BRI), based on two earthquakes. Reproduced from Chang and others (2014). Mw, moment magnitude. 
In the following presentation, Art Frankel presented the results of 3-D simulations of magnitude 9 earthquakes in Cascadia generated as part of The M9 Project (Frankel and others, 2018; Wirth and others, 2018). Thirty different $M 9$ earthquake scenarios were simulated from a logic tree and used to evaluate ground motion amplification in the Puget Lowland basins. Broadband synthetic seismograms $(0-10 \mathrm{~Hz})$ were generated by combining results from (1) the 3-D simulations computed using the Stephenson and others (2017) velocity model at frequencies $<1 \mathrm{~Hz}$, with (2) stochastic synthetics for frequencies $>1 \mathrm{~Hz}$. Slip on the fault consists of multiple high-stress drop subevents, superimposed on a background slip distribution. This approach has been shown to accurately reproduce ground motions from the 2003 M8.3 Tokachi-oki (Wirth and others, 2017) and 2010 M8.8 Maule, Chile (Frankel, 2017) earthquakes.

The basin amplification factors as a function of period for the Seattle basin using the $M 9$ simulations and observations for an M5.0 Satsop earthquake are shown in figure 5. The Satsop earthquake is a shallow crustal earthquake west of the Seattle basin, and therefore travels a similar path to seismic waves generated by an $M 9$ megathrust earthquake; we would expect this to result in somewhat similar amounts of basin amplification. When taking the ratio of station QAW (inside the Seattle basin) to SP2 (rock site outside the basin), log-averaged amplification factors from the M9 simulations are $\sim 2-3$ for periods of 1-10 s. Amplification factors for the M5.0 Satsop earthquake range from $\sim 1.5$ to 5 for $1-10$ s periods. Both the $M 9$ simulations and the observational data yield amplification factors that are significantly higher than the basin amplification factors predicted by Campbell and Bozorgnia (2014) and Chiou and Youngs (2014) using crustal earthquakes.

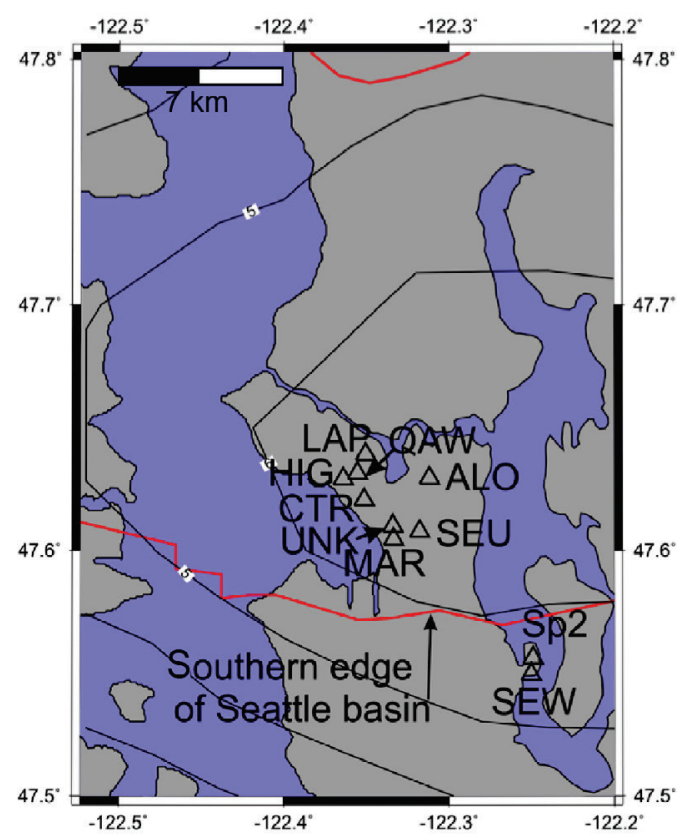

(a)

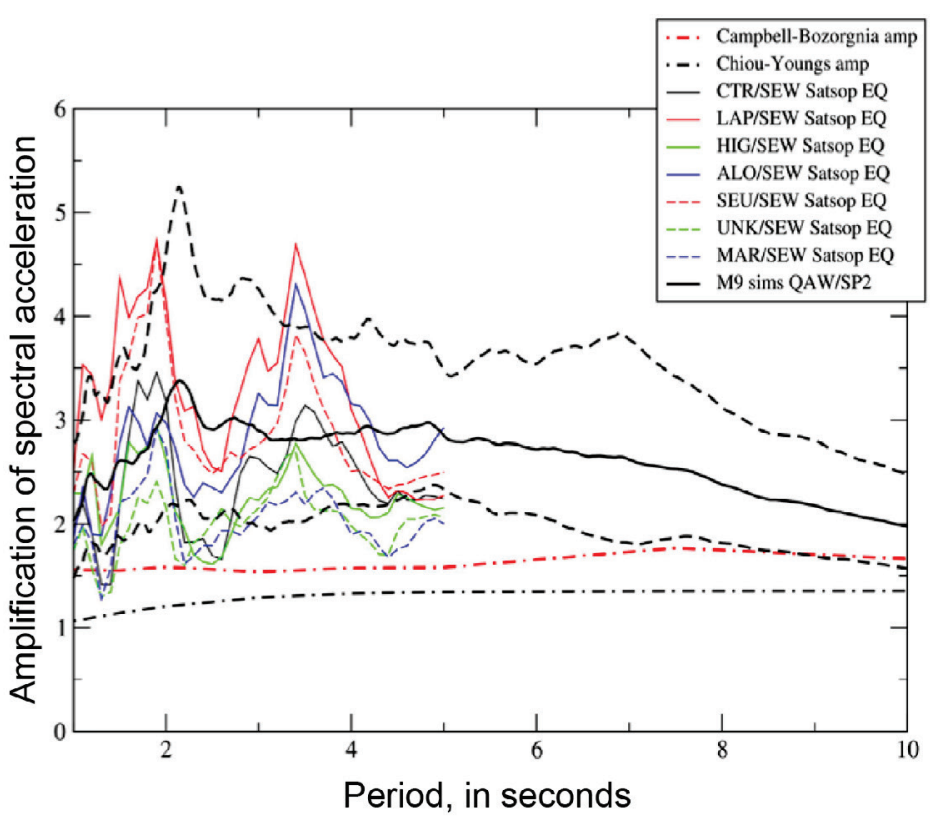

(b)

Figure 5. A, Map of select seismic stations in and around the Seattle basin. B, Amplification of Seattle basin sites relative to a rock site outside the basin, as a function of period. Results are shown for both $M 9$ earthquake simulations and observational data from an M5.0 Satsop earthquake. Amplification factors from various ground motion models are also shown. Reproduced from Frankel and others (2018). km, kilometer; $E Q$, earthquake; amp, amplification factor; sims, simulations. 
As an alternative to plotting ratios of single stations, basin amplification factors from the $M 9$ simulations were also computed using the average response of multiple stations. Basin amplification factors for 30 logic tree $M 9$ earthquake scenarios are shown in figure 6 (Nasser Marafi, University of Washington, written commun., 2018). Basin amplification factors were computed using an average residual (comparing to the BC Hydro GMM; Abrahamson and others, 2016) of all inside basin stations $\left(Z_{2.5} \geq 6 \mathrm{~km}\right)$ and an average residual of multiple reference sites $\left(Z_{2.5} \approx 3 \mathrm{~km}\right)$. More specifically, the basin amplification factor is calculated from

$\ln B A F=\frac{1}{n} \sum_{i=1}^{n}\left(\ln S A_{\text {basin synthetic }, i}-\ln G M M_{i}\right)-\frac{1}{m} \sum_{j=1}^{m}\left(\ln S A_{\text {ref site synthetic, } j}-\ln G M M_{j}\right)$

where $S A$ basin_synthetic,i is the response spectrum from the synthetics at basin site $i, S A$ ref_site synthetic,j is the response spectrum from the synthetics for reference site $j, G M M_{\mathrm{i}, \mathrm{j}}$ is the $\mathrm{BC}$ Hydro prediction for that site, $n$ is the number of sites within the basin, and $m$ is the number of reference sites. This is advantageous to single station ratios, as it minimizes the risk of error owing to localized effects at any particular station and the reference site condition can be tuned to the average $Z_{2.5}$ value of various GMM datasets (if available). The mean basin amplification factor from the $M 9$ simulations is $\sim 1.5$ at $1 \mathrm{~s}$, increasing to $\sim 2$ at periods greater than $2-3 \mathrm{~s}$ (fig. 6).

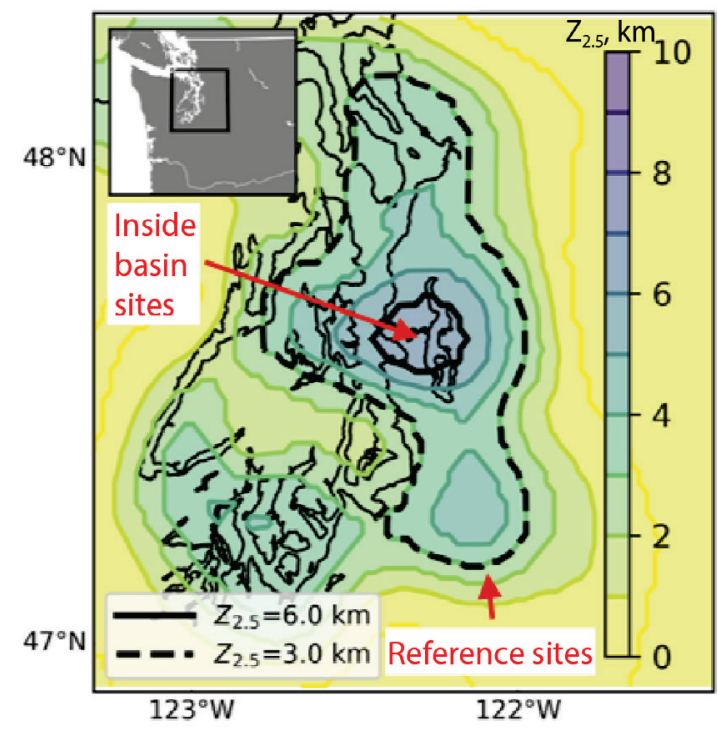

(a)

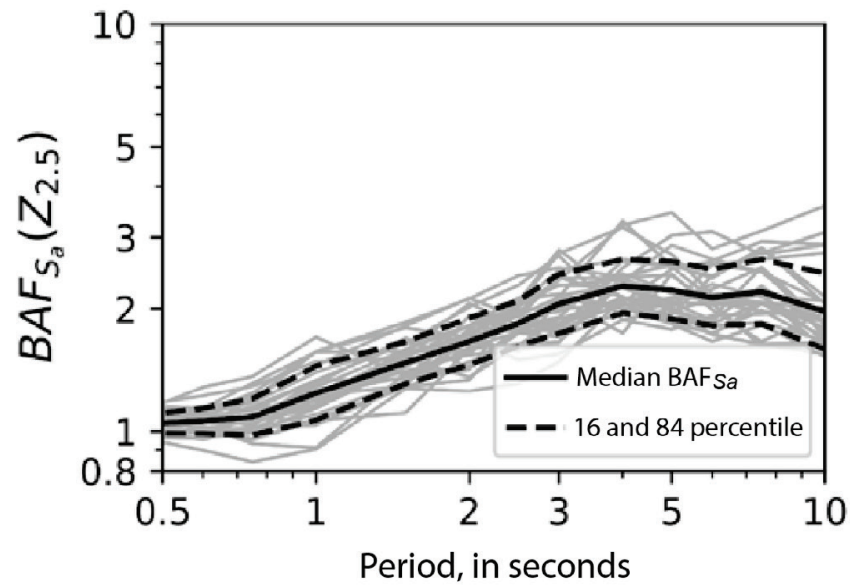

(b)

Figure 6. A, Seattle basin showing the depth to 2.5 kilometers per second shear wave velocity $\left(Z_{2.5}\right)$. Insidebasin stations are defined as those with $Z_{2.5} \geq 6.0$ (solid line), and outside-basin stations are those with $Z_{2.5} \approx 3 \mathrm{~km}$ (dashed line). $B$, Basin amplification as a function of period for the $M 9$ simulations, using the $Z_{2.5}$ criteria and station averages. Figure courtesy of Nasser Marafi, University of Washington. $Z_{2.5}$, the depth to 2.5 kilometers per second shear wave velocity; BAFsa, basin amplification factor; km, kilometer.

Frankel also discussed why the $M 9$ simulations and recorded data in Seattle might yield higher basin amplification factors than the NGA-West2 GMMs. This includes more shallowly incident seismic waves from a Cascadia megathrust earthquake, which (1) more efficiently generate basin-edge converted surface waves, (2) produce incident surface waves that have different amplification than 
vertically propagating S-waves, and (3) that some of the basin amplification is absorbed in the $V_{\mathrm{S} 30}$ term in NGA-West2. Since $V_{\mathrm{S} 30}$ is similar for sites inside and outside the Seattle basin, this would not be applicable to basin amplification in Seattle.

Andreas Skarlatoudis presented work on ground motion amplification in Japanese basins during the 2011 Tohoku earthquake (Skarlatoudis and others, 2018). This was done through either an empirical (using observational data) or theoretical (using simulated data) approach. In the empirical approach, recordings of strong ground motions were compared to GMMs without basin effects in order to determine a basin amplification factor. The resulting amplification factors were relative to the site conditions used by the empirical models. In the theoretical approach, basin amplification factors were derived from simulated strong ground motions at basin sites using a 3-D seismic velocity model, and with respect to simulations for a reference 1-D non-basin model with $V_{\mathrm{S} 30}=500$ meters per second [m/s].

Using both approaches, the amplifications obtained in the Kanto and Niigata basins in central Japan ranged from 1.25 to 1.4 for spectral periods of $2-10 \mathrm{~s}$. This is in general agreement with the results of Marafi and others (2017), which estimated amplification factors up to a factor of $\sim 1.5$ and $\sim 2.0$ for the Kanto and Niigata basins, respectively. The agreement between measured and simulated basin amplification factors in the Kanto and Niigata basins demonstrates the benefits of using simulation methods to estimate amplification for specific basins, particularly in regions where earthquake recordings may be sparse. However, these values are lower than the basin amplification factors determined for the Yufutsu and Konsen basins in northern Japan, as well as the Puget Lowland during the 2001 Nisqually earthquake (Marafi and others, 2017).

C.B. Crouse described a recent effort by the Utilization of Ground Motion Simulation committee of the Southern California Earthquake Center to develop site-specific MCER response spectra for Los Angeles using 3-D simulations and the NGA-West2 ground motion models (Crouse and others, 2018). For periods $<2 \mathrm{~s}$, the response spectra were computed exclusively from the NGA-West2 GMMs with basin terms. For periods $\geq 2 \mathrm{~s}$, a procedure was developed to combine the NGA-West 2 derived response spectra, with results from 3-D ground motion simulations of 40,000 regional earthquakes $(M \geq 6)$ using CyberShake. A web-based lookup tool allows users to obtain the MCER response spectrum $(0-10 \mathrm{~s})$ for a particular latitude and longitude, including a specified site class or $V_{\mathrm{S} 30}$. This serves as an important resource to city and county officials, as well as geotechnical and structural engineers, for incorporating results of 3-D simulations into building design.

\section{Code Updates and Structural Design}

C.B. Crouse presented various updates to the ASCE 7-16 and 7-22 building codes, and supplied the authors with the following text. Site coefficients, $F_{\mathrm{a}}, \mathrm{F}_{\mathrm{v}}$, and FPGA have been updated and are published in the ASCE 7-16 standard. Sections 11.4.8 and 21.4 of this standard, and in the forthcoming Supplement 1, were also revised. The new site coefficients, which were developed from a statistical analysis of ground motions in the NGA-West2 ground motion database, replace the $\sim 25$-year-old coefficients in previous editions of ASCE 7. In Seattle, the consequence of this update was an increase in the site factors used to adjust a $V_{\mathrm{S}}=760 \mathrm{~m} / \mathrm{s}$ ( site class $\mathrm{B} / \mathrm{C}$ ) design spectrum to account for local site effects (in other words, a softer or stiffer site); $F_{a}$ coefficients for site class $C$ increased by 20 percent, and a similar increase in $F_{\mathrm{v}}$ was seen for site class $\mathrm{D}$.

Section 11.4 .8 (formerly 11.4.7) and Section 21.4 were revised to account for differences in spectral shape between the design response spectral shape in Section 11.4.6 (formerly 11.4.5) and the actual spectral shape for soils in site classes D and E in the higher ground motion areas. Site-specific studies are now required in these cases, unless the structural engineer opts to use one of the three exceptions that were included in Section 11.4.8. For example, taking exception 2 for site class D in 
downtown Seattle was shown to result in a significant increase in the seismic response coefficient $\left(\mathrm{C}_{\mathrm{s}}\right)$ used in the equivalent lateral force procedure in Section 12.8 (in other words, the building will now need to be designed for a higher lateral load), for structures with natural periods between $\sim 0.7 \mathrm{~s}$ and $3 \mathrm{~s}$.

Possible revisions to the ASCE 7-16 standard that may appear in the ASCE 7-22 standard, expected to be published in 2022, include the introduction of multiperiod response spectra covering the period range from 0 to $10 \mathrm{~s}$, three new site classes $(\mathrm{BC}, \mathrm{CD}$, and $\mathrm{DE})$, and the elimination of the sitecoefficient tables.

Andy Taylor spoke about upcoming building code changes, irrespective of any changes in how basin effects are handled. Several changes in the ASCE 7-16 will lead to increases in minimum base shear calculations, including the elimination of a 0.85 multiplier when response spectrum analysis is performed, general increases in mapped spectral accelerations, changes in the site coefficients $F_{a}$ and $F_{v}$, and additional penalties on non-site class D locations. The net effect is a possible 20-70 percent increase in minimum base shear.

Significant structural code changes in the American Concrete Institute's (ACI) 318-19 are also likely and will affect the design of tall buildings. This includes defining coupled shear walls as a new structural system (this particular change will likely increase $R$ and decrease base shear), a drift capacity check and wall shear amplification factor may be imposed, grade 80 reinforcement may be permitted, and there may be new reinforcement detailing rules for walls. The overall effect of these changes will be a large increase in design shear forces for walls, likely increases in shear wall thickness, and a likely net increase in reinforcement congestion.

Taylor also provided an example of the effects of increasing the basin amplification factor for M9 earthquakes on the design of a 40-story building using the current code provisions. If the basin amplification factor were to increase to 3.2 (compared to the current value of 1.6), interstory drifts would increase from an average of $\sim 1$ percent to an average of $\sim 4$ percent. An average interstory drift $>3$ percent is not permitted for performance-based design buildings in Seattle. Concrete coupling beam end rotations would increase from an average of $\sim 0.02$ radians to an average of $\sim 0.07$ radians. Coupling beam end rotations $>0.05$ radians are typically avoided because the coupling beams begin to lose flexural strength.

Kevin Aswegan, as a representative of the ASCE 7-22 Seismic Subcommittee, spoke about the impacts of increasing Seattle basin amplification on structural design. To illustrate the effect on structural demands, an example 400-foot-tall concrete building with a special reinforced concrete shear wall seismic force-resisting system was analyzed. This example building was considered representative of residential towers in Seattle. Hart Crowser provided several potential design spectra, including (1) ASCE 7-10, site class C code spectrum, (2) ASCE 7-16, site class C code spectrum, (3) MCER sitespecific spectrum with no $B A F \mathrm{~s}$, (4) site-specific MCER spectrum with $B A F$ s included from the NGAWest2 GMMs, and (5) site-specific MCER spectrum with $B A F$ s included through a hybrid weighting scheme combining the NGA-West $2 B A F$ s and the $B A F$ s suggested by preliminary $M 9$ earthquake simulations. At the fundamental period of the structure $(3.3 \mathrm{~s})$, the spectrum including the $M 9$ results is 35 to 40 percent larger than the code spectra.

The spectrum including the $M 9$ results produced building lateral drifts approximately 33 percent larger than the spectrum using only NGA-West2 basin amplification factors. To account for the larger demands, Aswegan estimates this would result in approximately $\$ 8$ to $\$ 10$ per square foot of additional building costs. For the sample building, this is a total of $\$ 5,000,000$ to $\$ 6,000,000$. Owing to the relative regularity of the structure, which is not common in real buildings, it is expected that this estimate would be a lower bound of the economic impact on actual buildings. Additional costs would be incurred if 
commonly employed lateral systems (for example, central core walls) were now found to no longer be adequate for the larger seismic demands.

\section{Discussion}

\section{Applicability of Ground Motion Models and Basin Amplification Factors to Subduction Zone Earthquakes}

Participants of the 2013 workshop recommended that basin amplification factors from crustal earthquake ground motion models should be applied to the uniform hazard spectrum, even for subduction zone earthquakes. This approach was considered appropriate until basin amplification factors were developed for subduction zone earthquakes. However, new research has demonstrated that basin amplification factors derived from crustal earthquakes and (or) for other sedimentary basins are not appropriate for Cascadia subduction zone earthquakes, and alternative estimates on Seattle basin amplification owing to subduction zone earthquakes are now available (for example, the $M 9$ simulations, as well as recorded observations from earthquakes with similar depths and azimuths as a megathrust event). As presented by Art Frankel (fig. 5), the $M 9$ simulations and a recorded M5.0 earthquake near Satsop, Washington, both exhibit amplification factors between 1.5 and 5 at periods of 1-10 s. These values are significantly higher than the basin amplification factors derived from GMMs based on crustal earthquakes primarily located in California (for example, $\sim 1.6$ in Campbell and Bozorgnia, 2014; 1.3 in Chiou and Youngs, 2014).

When using simulation data, we are not restricted by the actual distribution of seismic stations when computing basin amplification factors. Thus, basin amplification factors can be computed based on averages of inside-basin stations to outside-basin stations (fig. 6). Using this approach and a reference site condition of $Z_{2.5} \approx 3 \mathrm{~km}$, the median basin amplification factor from the $M 9$ simulations is about a factor of $\sim 2$ for periods of $2-10 \mathrm{~s}$.

The workshop participants concluded that basin amplification terms developed for crustal earthquakes may not be appropriate for subduction zone earthquakes (that is, interface or intraslab). For subduction zone interface earthquakes and sites within the Seattle basin, the workshop participants recommended the following basin amplification factors:

- $B A F=1.0$ at period $=0 \mathrm{~s}$

- $B A F=1.5$ at period $=1 \mathrm{~s}$

- $B A F=2.0$ at period $\geq 2 \mathrm{~s}$

Linear interpolation should be used to determine basin amplification factors for periods between $0-2 \mathrm{~s}$. In the near future, Norm Abrahamson agreed to provide the average $\mathrm{Z}_{2.5}$ value from the BC Hydro GMM. This will provide an appropriate reference site condition for determining basin amplification factors centered on that particular GMM (fig. 6).

For intraslab earthquakes, the workshop participants recommended that observed Seattle basin amplification factors (fig. 4) from local and regional earthquakes should be used.

\section{Definition of the Seattle Basin}

Workshop participants discussed the regional extent of the Seattle basin, for which the amplification factors detailed above should be applied. Richard Blakely (USGS) has provided a geologic definition of the Seattle basin based on depth-to-basement estimates (fig. 7). The guidelines are as follows: 
- The eastern and western margins of the Seattle basin are approximately defined by the 500-meter depth-to-basement contour,

- The northernmost strand of the Seattle Fault, taken from the USGS Quaternary Fault and Fold Database, defines the southern margin,

- The northern margin is poorly constrained from current data, but is presently defined by a sediment thickness of $2.0-2.5 \mathrm{~km}$.

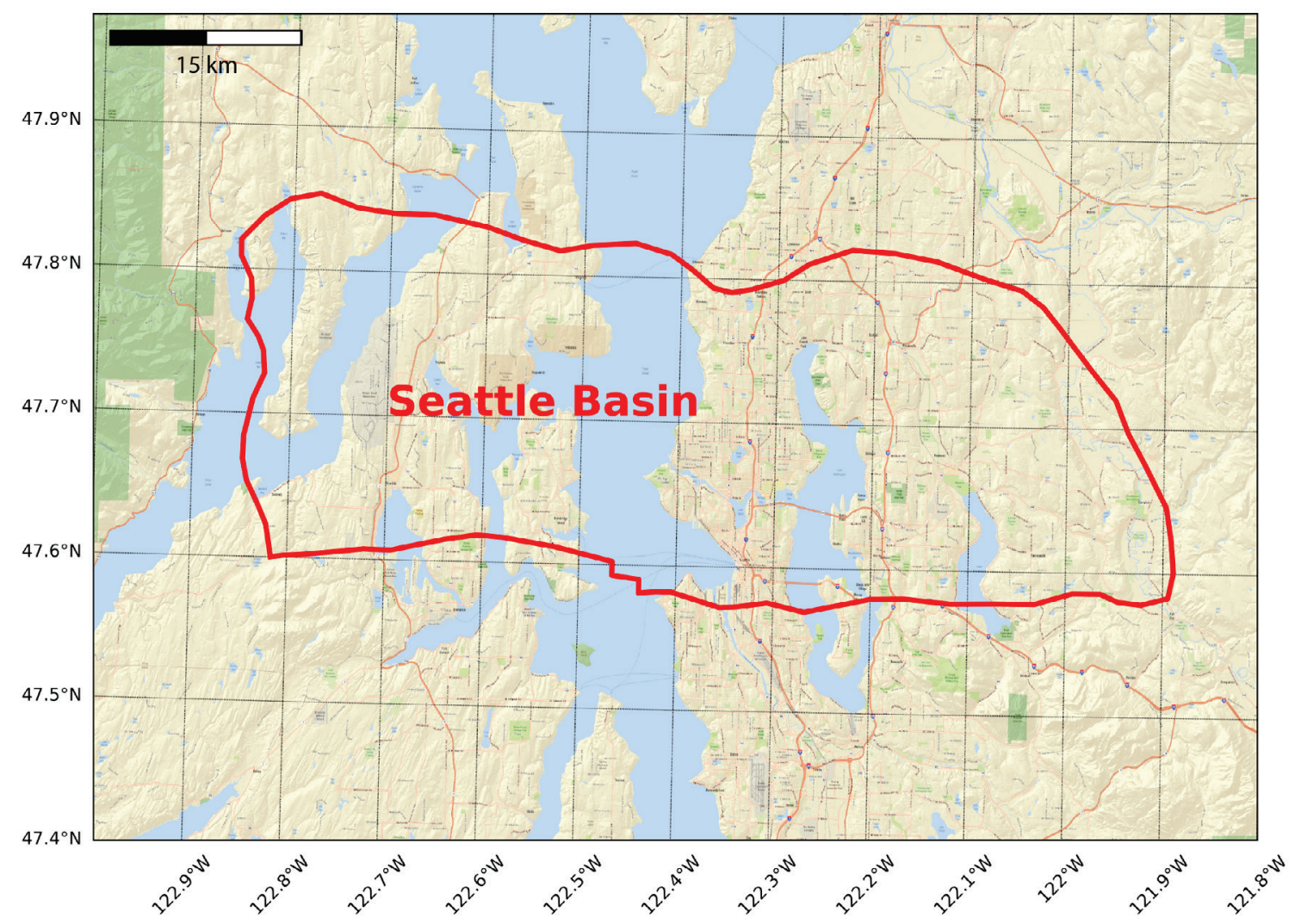

Figure 7. Geologic definition of the Seattle basin (red outline), based on depth-to-basement estimates and the location of the Seattle Fault. Data courtesy of Richard Blakely, U.S. Geological Survey. Static street map image from http://server.arcgisonline.com/arcgis/rest/services/ESRI_StreetMap_World_2D/MapServer. km, kilometer.

\section{The Influence of Reference Site on Basin Amplification Terms}

Basin amplification factors for specific ground motion models are generally based on a site's $Z_{1.0}$ (for example, Chiou and Youngs, 2014) or Z2.5 (for example, Campbell and Bozorgnia, 2014) value. In California, $Z_{1.0}$ and $Z_{2.5}$ have a demonstrated correlation with basin amplification factors for a particular site. However, the relations between $V_{\mathrm{S} 30}, \mathrm{Z}_{1.0}, \mathrm{Z}_{2.5}$, and basin depth are regionally dependent. In Seattle, local $Z_{1.0}$ values can be quite shallow owing to overlying glacial soils. Thus, this value is not representative of the deeper $V_{\mathrm{S}}$ profile. These sites often exhibit velocity inversions with depth; therefore, sites with a shallow $Z_{1.0}$ value can still have a deep $Z_{2.5}$ value. Overall, these complications 
with $\mathrm{Z}_{1.0}$ led the workshop participants to recommend the use of $\mathrm{Z}_{2.5}$ for computing basin amplification factors within the Seattle basin.

Art Frankel showed an example comparing seismic station DOSE (rock site outside of the Puget Lowland, in the Olympic Mountains) to station BRI (rock site outside of the Seattle basin, but within the Puget Lowland). DOSE and BRI both have similar $\mathrm{Z}_{1.0}$ values $<50 \mathrm{~m}$. Therefore, if one were using $\mathrm{Z}_{1.0}$ to compute basin amplification factors for these two sites, they would be very similar. However, DOSE has a $Z_{2.5}=1 \mathrm{~km}$ and BRI has $Z_{2.5}=5 \mathrm{~km}$. Variations in site amplification between each of these sites is clearly illustrated by data from a 2011 M6.4 Vancouver Island earthquake, for which BRI exhibits large ground motion amplifications relative to site DOSE at periods $\geq 1 \mathrm{~s}$. Therefore, Seattle basin amplification factors computed using DOSE as a reference station would be significantly larger than those computed using BRI as the reference site.

\section{Regional Variations Among Sedimentary Basins}

Several of the workshop participants expressed concern about applying basin amplification factors derived from other basins (for example, Kanto basin, Japan) to Seattle. Figure 3 illustrates the vast difference in basin amplification factors as a function of period between the Nisqually earthquake in the Seattle basin and various earthquakes around the Kanto basin in Japan (Marafi and others, 2017). The Kanto basin exhibits considerably lower basin amplification factors of $\sim 1-1.5$ at periods of $1-10 \mathrm{~s}$, as well as an opposite trend in $B A F$ as a function of period. Similarly, Skarlatoudis and others (2018) computed basin amplification factors of $\sim 1.2-1.4$ for the Kanto and Niigata basins, using observations and simulations of the 2011 M9.0 Tohoku earthquake and two aftershocks. Given the differences between basin amplification in the Seattle and Kanto basins, it is clearly preferable to use regional information (for example, earthquake observations or 3-D simulations) to constrain basin amplification factors in Seattle.

\section{Recommendations by the Workshop Participants}

1. The workshop participants agreed to continue with the general procedure from the 2013 workshop in which basin response for tall building design is captured by multiplying the MCER spectrum from a site-specific PSHA by basin amplification factors. The basin amplification factors will be calculated for each type of earthquake source and weighted by percent contribution of the source for each period. Participants recommend basin amplification factors should be applied to sites within the Seattle basin as approximately defined by geology, gravity, and aeromagnetic data. These include:

A. Crustal - Basin amplification factors from Campbell and Bozorgnia (2014) based on the $Z_{2.5}$ from the Stephenson and others (2017) velocity model are preferable.

B. Intraslab - Use observed Seattle basin amplification factors from local and regional earthquakes such as the M6.8 2001 Nisqually and the M6.4 2004 Vancouver Island earthquakes (fig. 4).

C. Interface - Use the results of The $M 9$ Project basin amplification factors with a reference site of $Z_{2.5} \approx 3 \mathrm{~km}$ (fig. 6). This results in basin amplification factors that increase from 1.0 to 2.0 between periods of 0 to 2 seconds, and then remains constant at 2.0 for periods greater than 2 seconds.

2. Workshop participants recommended that the average $Z_{2.5}$ value should be determined from the $\mathrm{BC}$ Hydro dataset. This will provide an appropriate reference $Z_{2.5}$ value for determining basin 
amplification. Once the reference $\mathrm{Z}_{2.5}$ is determined, the basin amplification factor of 2.0 for interface earthquakes (see recommendation 1) may be modified.

3. Once available, the NGA-Subduction ground motion models will be used for evaluating shaking intensity resulting from interface earthquakes. NGA-Subduction basin amplification terms will need to be assessed for their applicability to the Seattle basin; however, it is likely that they will not be representative of basin amplification in the Puget Lowland. Any regionally specific basin terms (from 3-D simulations or recorded observations) will need to be centered on the NGASubduction GMM.

4. Over the long term, the USGS should validate basin amplification resulting from the 2001 Nisqually earthquake using the newest version of the Cascadia 3-D seismic velocity model (Stephenson and others, 2017). In addition, results from future 3-D simulations for Seattle Fault and Southern Whidbey Island Fault earthquakes should be evaluated by third parties for use in design. The epistemic and aleatory uncertainty associated with the basin amplification factors should also be further investigated.

\section{References Cited}

Abrahamson, N., Gregor, N., and Addo, K., 2016, BC Hydro ground motion prediction equations for subduction earthquakes: Earthquake Spectra, v. 32, no. 1, p. 23-44. [Also available at http://dx.doi.org/10.1193/051712EQS188MR.]

Abrahamson, N., and Silva, W., 2008, Summary of the Abrahamson \& Silva NGA ground-motion relations: Earthquake Spectra, v. 24, no. 1, p. 67-97. [Also available at http://dx.doi.org/10.1193/1.2924360.]

Abrahamson, N.A., Silva, W.J., and Kamai, R., 2014, Summary of ASK14 ground motion relation for active crustal regions: Earthquake Spectra, v. 30, no. 3, p. 1,025-1,055. [Also available at http://dx.doi.org/10.1193/070913EQS198M.]

Campbell, K.W., and Bozorgnia, Y., 2014, NGA-West2 ground motion model for the average horizontal components of PGA, PGV, and 5\% damped linear acceleration response spectra: Earthquake Spectra, v. 30, no. 3, p. 1,087-1,115. [Also available at http://dx.doi.org/10.1193/062913EQS175M.]

Chang, S.W., Frankel, A.D., and Weaver, C.S., 2014, Report on workshop to incorporate basin response in the design of tall buildings in the Puget Sound region, Washington: U.S. Geological Survey, OpenFile Report 2014-1196, 28 p. [Also available at http://dx.doi.org/10.3133/ofr20141196.]

Chiou, B.S.-J., and Youngs, R.R., 2014, Update of the Chiou and Youngs NGA model for the average horizontal component of peak ground motion and response spectra: Earthquake Spectra, v. 30, no. 3, p. 1,117-1,153. [Also available at http://dx.doi.org/10.1193/072813EQS219M.]

Crouse, C.B., Jordan, T., Milner, K., Goulet C., Callaghan, S., and Graves, R., 2018, Site-specific MCER response spectra for Los Angeles region based on 3-D numerical simulations and NGA West2 equations: Proceedings of the 11th National Conference in Earthquake Engineering, Earthquake Engineering Research Institute, Los Angeles, Calif, 5 p.

Day, S.M., Graves, R., Bielek, J., Dreger, D., Larsen, S., Olsen, K.B., Pitarka, A., and RamirezGuzman, L., 2008, Model for basin effects on long-period response spectra in southern California: Earthquake Spectra, v. 24, no. 1, p. 257-277. [Also available at http://dx.doi.org/10.1193/1.2857545.] Delorey, A.A., and Vidale, J.E., 2011, Basin shear-wave velocities beneath Seattle, Washington, from noise-correlation Rayleigh waves: Bulletin of the Seismological Society of America, v. 101, no. 5, p. 2,162-2,175. [Also available at http://dx.doi.org/10.1785/0120100260.] 
Denolle, M.A., Miyake, H., Nakagawa, S., Hirata, N., and Beroza, G.C., 2014, Long-period seismic amplification in the Kanto Basin from the ambient seismic field: Geophysical Research Letters, v. 41, p. 2,319-2,325. [Also available at http://dx.doi.org/10.1002/2014GL059425.]

Frankel, A., 2017, Modeling strong ground-motion recordings of the $2010 M_{\mathrm{w}} 8.8$ Maule, Chile, earthquake with high stress-drop subevents and background slip: Bulletin of the Seismological Society of America, v. 107, no. 1, p. 372-386. [Also available at http://dx.doi.org/10.1785/0120160127.]

Frankel, A., and Stephenson, W., 2015, 3D simulations of M9 Cascadia earthquakes-Sedimentary basin amplification and ground-motion variability: 2015 Seismological Society of America Annual Meeting, Pasadena, Calif., 1 p.

Frankel, A., Stephenson, W., and Carver, D., 2009, Sedimentary basin effects in Seattle, WashingtonGround motion observations and 3D simulations: Bulletin of the Seismological Society of America, v. 99, no. 3, p. 1,579-1,611. [Also available at http://dx.doi.org/10.1785/0120080203.]

Frankel, A., Wirth, E., Marafi, N., Vidale, J., and Stephenson, W., 2018, Broadband synthetic seismograms for magnitude 9 earthquakes on the Cascadia megathrust based on 3D simulations and stochastic synthetics (Part 1)—Methodology and overall results: Bulletin of the Seismological Society of America, in press, accessed August 2018, at http://dx.doi.org/10.1785/0120180034.

Marafi, N.A., Eberhard, M.O., Berman, J.W., Wirth, E.A., and Frankel, A.D., 2017, Effects of deep basins on structural collapse during large subduction earthquakes: Earthquake Spectra, v. 33, no. 3, p. 963-997. [Also available at http://dx.doi.org/10.1193/071916EQS114M.]

Skarlatoudis, A.A., Somerville, P., and Hosseini, M., 2018, Basin amplification factors for Cascadia estimated from the 2011 Tohoku, Japan, earthquake: Proceedings of the 11th National Conference in Earthquake Engineering, Earthquake Engineering Research Institute, Los Angeles, Calif., 11 p.

Stephenson, W.J., Reitman, N.G., and Angster, S.J., 2017, P- and S-wave velocity models incorporating the Cascadia subduction zone for 3D earthquake ground motion simulations, ver. 1.6-Update for Open-File Report 2007-1348: U.S. Geological Survey Open-File Report 2017-1152, 17 p. [Also available at http://dx.doi.org/10.3133/ofr20171152.]

Wirth, E.A., Frankel, A.D., Marafi, N., Vidale, J.E., and Stephenson, W.J., 2018, Broadband synthetic seismograms for magnitude 9 earthquakes on the Cascadia megathrust based on 3-D simulations and stochastic synthetics (Part 2) - Rupture parameters and variability: Bulletin of the Seismological Society of America, in press, accessed August 2018, at http://dx.doi.org/10.1785/0120180029.

Wirth, E.A., Frankel, A.D., and Vidale, J.E., 2017, Evaluating a kinematic method for generating broadband ground motions for great subduction zone earthquakes-Application to the $2003 M_{\mathrm{w}} 8.3$ Tokachi-Oki earthquake: Bulletin of the Seismological Society of America, v. 107, no. 4, p. 1,7371,753. [Also available at http://dx.doi.org/10.1785/0120170065.] 


\section{Appendix}

\section{Agenda}

\begin{tabular}{|c|c|c|}
\hline \multicolumn{3}{|c|}{$\begin{array}{c}\text { U.S. Geological Survey/Seattle Dept. of Construction and Inspections Workshop } \\
\text { INCORPORATING RESULTS OF THE M9 PROJECT AND OTHER RECENT RESEARCH TO ESTIMATE BASIN EFFECTS IN THE } \\
\text { DESIGN OF TALL BUILDINGS } \\
\text { March 22, 2018 } \\
\text { Columbia Tower, } 701 \text { - 5th Avenue, Seattle, Washington } \\
\text { Columbia Tower Club (76th Floor) }\end{array}$} \\
\hline 8:00 a.m. & Room opens & Coffee available \\
\hline $8: 30$ to $8: 45$ & Welcome, Introductions, Charge & Susan Chang \\
\hline & Basin Factors from Ground Motion Models & \\
\hline $8: 45$ to $9: 00$ & Crustal GMM - how basin terms were developed, reference site & Ken Campbell \\
\hline $9: 00$ to $9: 15$ & $\begin{array}{l}\text { Crustal GMM - how basin terms were developed, US vs. Japan } \\
\text { terms, reference site }\end{array}$ & Norm Abrahamson \\
\hline $9: 15$ to $9: 20$ & NGA-subduction basin terms (if any) & Melanie Walling \\
\hline $9: 20$ to $9: 30$ & $\begin{array}{l}\text { Report on NSMP March 8, } 2018 \text { workshop - consideration of } \\
\text { basin terms in national maps }\end{array}$ & Art Frankel \\
\hline $9: 30$ to $9: 45$ & $\begin{array}{l}\text { Discussion: Will basin terms be included in NGA-subduction? } \\
\text { Would you expect basin amplification factors from } \\
\text { subduction sources to differ from crustal sources? }\end{array}$ & All participants \\
\hline \multirow[t]{2}{*}{$9: 45$ to $10: 00$} & Break & \\
\hline & Incorporation of Basin Response in Seattle & \\
\hline $10: 00$ to $10: 15$ & GeoEngineers & Hamilton Puangnak \\
\hline $10: 15$ to $10: 30$ & Hart Crowser & Doug Lindquist \\
\hline \multirow[t]{2}{*}{$10: 30$ to $10: 45$} & $\begin{array}{l}\text { Discussion: Comparison of basin amplification factors and } \\
\text { methods, comparison with current code, concerns with } \\
\text { current practice }\end{array}$ & All participants \\
\hline & Recent Research & \\
\hline $10: 45$ to $11: 00$ & $\begin{array}{l}\text { Basin amplification factors in Japan determined in: Effects of } \\
\text { Deep Basins on Structural Collapse During Large } \\
\text { Subduction Earthquakes by Marafi and others, Earthquake } \\
\text { Spectra, August 2017; observations of Seattle Basin } \\
\text { amplifications }\end{array}$ & Art Frankel \\
\hline $11: 00$ to $11: 15$ & $\begin{array}{l}\text { Broadband Synthetic Seismograms for Magnitude } 9 \\
\text { Earthquakes on the Cascadia Megathrust Based on 3D } \\
\text { Simulations and Stochastic Synthetics (Part 1): Methodology } \\
\text { and Overall Results, submitted to BSSA January } 2018\end{array}$ & Art Frankel \\
\hline $11: 15$ to $11: 30$ & $\begin{array}{l}\text { Basin Amplification Factors for Cascadia Based on the } 2011 \\
\text { Tohoku, Japan Earthquake, 11th NCEE, June } 2018\end{array}$ & Andreas Skarlatoudis \\
\hline $11: 30$ to $11: 45$ & $\begin{array}{l}\text { Site-Specific MCER Response Spectra for Los Angeles Region } \\
\text { Based on 3D Numerical Simulations and the NGA West2 } \\
\text { Equations, 11th NCEE, June } 2018\end{array}$ & C.B. Crouse \\
\hline \multirow[t]{2}{*}{$11: 45$ to $12: 30$} & Lunch & Provided by SDCI \\
\hline & Recent Research (continued) & \\
\hline
\end{tabular}


$12: 30$ to $1: 00$

1:00 to $1: 25$

$1: 25$ to $1: 35$

$1: 35$ to $1: 45$

$1: 45$ to $3: 45$

$2: 15$ to $2: 30$

$3: 45$ to $4: 30$

$4: 30$
Discussion: Strengths and limitations of the various 3D basin models (method of analysis, algorithms); how sensitive are computed basin amplification factors to the models used? Do we feel that these methods of analysis have been suitably calibrated to field data to the point that they should be used as the basis for engineering basin amplification factors?

Code Updates and Structural Design

Code updates (ASCE 7-16 and 7-22) - geotechnical

Upcoming code updates - structural

Effect on structural design with increased basin amplification factors

Roundtable Discussions

Do we continue with the methodology from the 2013 Workshop? If so, how do we weight the results of recent research? Any examples?

What other methodologies could we consider, for example, direct incorporation into PSHA?

Break

Recommendations for geotechnical practitioners

Implications for structural design

Schedule for implementing $M 9$ results

Directions for applied research
All participants

\author{
C.B. Crouse \\ Andy Taylor \\ Kevin Aswegan
}

All participants, moderated by Susan Chang

Group recommendations

All participants

End of workshop

\section{Attendees:}

Norm Abrahamson, Ph.D. (University of California, Berkeley)*

Kevin Aswegan, P.E. (Magnusson Klemencic Associates, ASCE-7 Seismic Committee)

Doug Beck, S.E. (City of Bellevue)

Kenneth Campbell, Ph.D. (CoreLogic)

Michael Chamberlain, P.E. (Hart Crowser)

Susan Chang, Ph.D., P.E. (Seattle Department of Construction and Inspections)

C.B. Crouse, Ph.D., P.E. (AECOM Seattle)

Stephen Dickenson, Ph.D., P.E., D.PE (New Albion Geotechnical)*

Marc Eberhard, Ph.D. (University of Washington)

Arthur Frankel, Ph.D. (USGS Seattle)

Matt Gibson, Ph.D., P.E. (formerly at Shannon \& Wilson)

Steve Kramer, Ph.D., P.E. (University of Washington)

Feng Li, Ph.D., P.E. (Golder Associates)

Doug Lindquist, P.E., G.E. (Hart Crowser)

Reda Mikhail Ph.D., P.E. (Golder Associates)

Scott Pawling, P.E. (Seattle Department of Construction and Inspections)

Hamilton Puangnak, P.E. (GeoEngineers)

Ali Shahbazian, Ph.D., P.E. (Shannon \& Wilson)

Andreas Skarlatoudis, Ph.D. (AECOM Los Angeles)

Andrew Taylor, Ph.D., S.E. (KPFF Seattle, SEAW Earthquake Engineering Committee) 
Melanie Walling, Ph.D. (GeoEngineers)

Erin Wirth, Ph.D. (USGS Seattle)

Ivan Wong, P.G. (Lettis Consultants International)

*via Skype

Menlo Park Publishing Service Center, California Manuscript approved September 13, 2018

Edited by Katherine Jacques Layout by Cory Hurd 